\title{
The effect of neurogenin3 deficiency on pancreatic gene expression in embryonic mice
}

\author{
Andreas Petri $^{{ }^{* 1,2}}$, Jonas Ahnfelt-Rønne ${ }^{\star 2}$, Klaus Stensgaard Frederiksen ${ }^{1}$, \\ David George Edwards ${ }^{3}$, Dennis Madsen ${ }^{4}$, Palle Serup ${ }^{2}$, Jan Fleckner ${ }^{1}$ and R Scott Heller ${ }^{2}$ \\ ${ }^{1}$ Department of Molecular Genetics, Novo Nordisk A/S, DK-2880 Bagsværd, Denmark \\ ${ }^{2}$ Department of Developmental Biology, Hagedorn Research Institute, DK-2820 Gentofte, Denmark \\ ${ }^{3}$ Department of Biostatistics, Novo Nordisk A/S, DK-2880 Bagsværd, Denmark \\ ${ }^{4}$ Department of Scientific Computing, Novo Nordisk A/S, DK-2760 Måløv, Denmark \\ (Requests for offprints should be addressed to R S Heller; Email: shll@ hagedorn.dk) \\ *(A Petri and J Ahnfelt-Rønne contributed equally to this work)
}

\begin{abstract}
To understand the molecular mechanisms regulating pancreatic endocrine development and function, pancreatic gene expression was compared between $\mathrm{Ngn3}$-deficient mice and littermate controls on embryonic days 13 and 15. Microarray analysis identified 504 genes with significant differences in expression. Fifty-two of these showed at least twofold reduction in Ngn3 knockouts compared to controls. Many of them were previously described to be involved in endocrine development and function. Among the genes not previously characterized were Rhomboid veinlet-like 4, genes involved in tetrahydrobiopterin biosynthesis and the Iroquois-type homeobox gene Irx1, the latter was selected for further investigation. In situ hybridisation demonstrated that two Iroquois genes, Irx1 and Irx2, were expressed in pancreatic endoderm of wild-type, but not Ngn3 mutant embryos. Furthermore, ectopic Ngn3 induced prominent Irx2 expression in chicken endoderm. Co-labelling established that Irx1 and Irx2 mRNA is located to glucagon-, but not insulin- or somatostatin-producing cells in mice and chicken. These data suggest that Irx1 and Irx2 serve an evolutionary conserved role in the regulation of $\alpha$-cell-specific gene expression.
\end{abstract}

Journal of Molecular Endocrinology (2006) 37, 301-316

\section{Introduction}

The pancreas is an organ located next to the duodenal part of the intestine and serves two main functions. It produces and secretes enzymes required for the digestion of proteins, carbohydrates, nucleic acids, as well as fats in the small intestine, and hormones including insulin and glucagon required for the regulation of blood glucose levels (Slack 1995). Three distinct populations of cells make up the adult pancreas. The acinar cells produce and secrete enzymes, the duct cells form a highly branched tube system facilitating delivery of enzymes to the intestine and the endocrine cells produce hormones. In adult pancreas, the endocrine cells constitute approximately $2 \%$ of the pancreas and are grouped into cell clusters known as islets of Langerhans. Five distinct cell types are discernible in the endocrine compartment. The majority of cells are insulin-producing $\beta$-cells, whereas glucagon-producing $\alpha$-cells, somatostatin-producing $\delta$-cells, pancreatic polypeptide-producing PP-cells and ghrelin-producing $\varepsilon$-cells constitute a minor fraction
(Slack 1995, Wierup et al. 2002, Prado et al. 2004, Heller et al. 2005).

At embryonic day 9 (e9), distinct patches of primitive gut epithelium start to evaginate and give rise to the dorsal and the ventral pancreatic buds (Slack 1995). These buds are characterized by homogeneous expression of pancreatic-duodenal homeobox 1 (Pdx1; Ohlsson et al. 1993) and these Pdx1-positive cells give rise to all cell types of the adult pancreas $(\mathrm{Gu}$ et al. 2003). As the buds grow, they invade the surrounding mesenchyme and the resulting epithelial-mesenchymal interactions facilitate further proliferation and differentiation (Kim \& Hebrok 2001). Several cell fate choices are required for the development of a complex organ like the pancreas from initially identical cells, and research done during the last decade has revealed several important steps of pancreas development (Murtaugh \& Melton 2003, Wilson 2003).

The basic helix-loop-helix transcription factor neurogenin3 (Ngn3) is a central player in the choice between exocrine and endocrine cell fate. The absolute 
requirement of this transcription factor for endocrine development was demonstrated by Gradwohl et al. (2000) who showed that mice lacking functional Ngn3 fail to develop endocrine cells, but develop an apparently normal exocrine pancreas although accumulation of secretory granules was observed at postnatal day 1 (Gradwohl et al. 2000). Transgenic mice expressing Ngn3 under the Pdx1 promoter have small underdeveloped pancreata consisting primarily of endocrine cells, showing that ectopic expression of Ngn3 is sufficient to drive $\mathrm{Pdx} 1+$ pancreatic precursor cells to an endocrine fate, thereby depleting the pool of pancreatic precursors capable of differentiating into exocrine tissue (Apelqvist et al. 1999, Jensen et al. $2000 b$, Schwitzgebel et al. 2000). Further evidence for the pro-endocrine nature of Ngn3 was provided by Grapin-Botton et al. (2001) by showing that in ovo electroporation of chicken endoderm with Ngn3expressing plasmids promoted endocrine differentiation, not only in the pancreas region but also in the entire primitive gut tube. However, both studies found that endocrine cells with an $\alpha$-cell fate was the predominant cell type produced by forced expression of Ngn3, indicating that additional factors are required for the development of $\beta$-cells. Ngn3 expression is turned off prior to terminal differentiation (Jensen et al. $2000 a$ ) and is thus not co-expressed with hormoneproducing islet cells. Functional studies have identified several transcription factors acting downstream of Ngn3, which are necessary for proper development of the endocrine cells.

Here we present the microarray analysis of $\mathrm{Ngn} 3$ deficient mice. A cDNA chip containing 20188 probes was used to compare a major part of the transcriptome in dorsal pancreas buds from wild-type and Ngn3deficient embryos isolated at e13 and e15. In wild-type mice, these days mark the beginning and the end of the secondary transition, a stage of pancreas development where the majority of endocrine cells differentiate (Murtaugh \& Melton 2003). The aim of this study is to identify genes expressed in endocrine cells and their precursors and to map important pathways that operate during the formation of the endocrine cells.

\section{Materials and methods}

\section{Tissue isolation}

Time-mated Ngn3-mutant mice (Gradwohl et al. 2000) were killed by cervical dislocation at e13 and e15. The dorsal pancreatic bud was isolated from embryos and stored in RNAlater (Ambion, Austin, TX, USA) at $4{ }^{\circ} \mathrm{C}$ overnight. The next day, RNAlater was removed and the tissue was stored at $-80^{\circ} \mathrm{C}$.

\section{Genotyping}

Genotyping of the embryos was done by PCR analysis on genomic DNA isolated from forelimbs, as described by Gradwohl et al. (2000), using BioTaq polymerase (Bioline GmbH, Luckenwalde, Germany) according to the manufacturer's recommendations. Genomic DNA was extracted by incubating $50 \mathrm{mM}$ Tris $(\mathrm{pH} 8)$, $100 \mathrm{mM}$ EDTA and $0.5 \% \mathrm{SDS}$, in $10 \mathrm{mg} / \mathrm{ml}$ proteinase $\mathrm{K}$, at $55{ }^{\circ} \mathrm{C}$ overnight. Proteins were precipitated by the addition of $\mathrm{NaCl}$ to a final concentration of $1.3 \mathrm{M}$ and the lysate was cleared by centrifugation at $10000 \mathrm{~g}$ for 5 min. Supernatants were transferred to a clean tube and nucleic acids precipitated by the addition of $0.5 \mathrm{vol}$ isopropanol, followed by gentle mixing and centrifugation at $10000 \mathrm{~g}$ for $10 \mathrm{~min}$. The pellet was washed in $70 \% \mathrm{EtOH}$ followed by $96 \% \mathrm{EtOH}$ and finally resuspended in $100 \mu \mathrm{l}$ Milli-Q water. Thermal cycling was done in a PTC-200 Peltier Thermal Cycler (MJ Research, Waltham, MA, USA) for 30 cycles of $94^{\circ} \mathrm{C}$ for $30 \mathrm{~s}, 60{ }^{\circ} \mathrm{C}$ for $30 \mathrm{~s}$, and $72{ }^{\circ} \mathrm{C}$ for $1 \mathrm{~min}$. PCR products were visualized by agarose gel electrophoresis in the presence of EtBr.

\section{Total RNA isolation}

Mini RNA isolation kit (Zymo Research, Orange, CA, USA) was used to isolate total RNA from pancreas tissue using manufacturer's instructions with a few changes. After addition of lysis buffer, the tissue was homogenized using disposable pistils for $1.5 \mathrm{ml}$ Eppendorf tubes (Buch\&Holm, Herlev, Denmark). The wash buffer was substituted with $80 \% \mathrm{EtOH}$ and the total RNA was eluted with Milli- $Q$ water. Subsequently, the integrity and the quantity of the purified RNA were determined on a Bioanalyzer 2100 (Agilent, Palo Alto, CA, USA) using the Eukaryotic Total RNA Nano chip (Agilent) as described by the manufacturer.

\section{Sample labelling}

The total RNA from dorsal pancreata was amplified using a combination of the RiboAmp kit (Arcturus, Mountain View, CA, USA) and T7 MEGAscript kit (Ambion). Briefly, generation and purification of double-stranded cDNA was done with components from the Arcturus kit following the manufacturer's recommendations. The resulting cDNA was in vitro transcribed using components from the MEGAscript kit and aminoallyl-modified UTP (aa-UTP; Sigma). Briefly, the generated double-stranded cDNA was in vitro transcribed in $40 \mathrm{ml}$ reactions $(1 \times \mathrm{T} 7$ reaction buffer, $7.5 \mathrm{mM}$ ATP, $7.5 \mathrm{mM} \mathrm{CTP}, 7.5 \mathrm{mM}$ GTP, $3.75 \mathrm{mM} \mathrm{UTP}$, $3.75 \mathrm{mM}$ aa-UTP and $4 \mu \mathrm{l} 7$ Enzyme Mix) at $37^{\circ} \mathrm{C}$ for $5 \mathrm{~h}$. Subsequently, the cDNA template was digested with $4 \mathrm{U}$ DNaseI for $15 \mathrm{~min}$ at $37^{\circ} \mathrm{C}$ and amino allyl cRNA 
was purified on RNeasy columns (Qiagen). Manufacturer's recommendations were modified by replacing the RPE wash buffer with $80 \% \mathrm{EtOH}$, adding an additional wash step and eluting the aa-cRNA from the columns in two times $30 \mu \mathrm{l}$ Milli-Q water. The purified aa-cRNA was split into $2 \mu \mathrm{g}$ aliquots, completely dried in a SpeedVac (Holm and Halby, Brøndby, Denmark) and stored at $-20^{\circ} \mathrm{C}$. Coupling of fluorescent dyes to aa-cRNA was done by mixing $2 \mu \mathrm{g}$ aa-cRNA resuspended in $4.5 \mu \mathrm{l}$ freshly made $0 \cdot 1 \mathrm{M}$ sodium carbonate buffer ( $\mathrm{pH} 9 \cdot 0$ ) with Alexa Fluor 555 or Alexa Fluor 647 succinimidyl ester (Molecular Probes, Eugene, OR, USA) resuspended in $4.5 \mu \mathrm{l}$ dimethyl sulfoxide (DMSO) (Sigma) and incubating at $25^{\circ} \mathrm{C}$ for $1 \mathrm{~h}$. Subsequently, uncoupled succinimidyl ester dyes were quenched by the addition of $4.5 \mu \mathrm{l}, 4 \mathrm{M}$ hydroxylamine and incubating for $15 \mathrm{~min}$ at $25^{\circ} \mathrm{C}$. Labelled cRNA was purified on RNeasy columns with the following modifications to manufacturer's protocol. An additional wash step with $500 \mu \mathrm{l}$ RPE buffer was added and the dye-coupled cRNA was eluted two times in $40 \mu \mathrm{l}$ Milli-Q water. Labelling efficiency and concentration of nucleic acid were determined by measuring absorbance of the cRNA-dye conjugate at $\lambda$-max of the dye and $260 \mathrm{~nm}$ respectively. All incubation steps were done in a MJ Research PTC-200 Peltier Thermal Cycler.

\section{Microarray}

The ArrayTAG 20k murine gene collection (LION Bioscience AG, Heidelberg, Germany) was spotted in duplicate on CodeLink slides (GE Healthcare, Hillerød, Denmark) using a BioRobotics Microgrid II spotter (Genomic Solutions Ltd, Cambridgeshire, UK). Probes contained an amino modification at the $5^{\prime}$ end of the sense strand allowing specific covalent coupling of the sense strand to N-hydroxysuccinimide ester groups on the slide. Prior to hybridisation, residual reactive groups on the slide were blocked by incubating, $0 \cdot 1 \mathrm{M}$ Tris ( $\mathrm{pH} 9$ ), in $50 \mathrm{mM}$ ethanolamine, at $50{ }^{\circ} \mathrm{C}$ for $30 \mathrm{~min}$. Slides were rinsed twice with deionised water and incubated in $4 \times \mathrm{SSC}, 0 \cdot 1 \%$ SDS for $30 \mathrm{~min}$. Subsequently, slides were rinsed in deionised water and placed in boiling water for $2 \mathrm{~min}$ to render the covalently attached probes single stranded. Following two additional rinses with water, the slides were prehybridised in digoxigenin (DIG) Easy $\mathrm{Hyb}$ buffer (Roche) for $30 \mathrm{~min}$ at $42^{\circ} \mathrm{C}$. Finally, slides were rinsed twice in water and dried using compressed air. Dyeconjugated cRNA corresponding to $30 \mathrm{pmol}$ of each fluorescent dye was mixed with $7 \mu \mathrm{g}$ mouse Cot-1 DNA (Invitrogen) and $1 \mu \mathrm{g}$ poly dA (DNA technology, Århus, Denmark). The hybridisation mix was dried in a SpeedVac and resuspended in $80 \mu \mathrm{l}$ digoxigenin (DIG) Easy Hyb buffer. Nucleic acids of the hybridisation mix were denatured at $95^{\circ} \mathrm{C}$ for $2 \mathrm{~min}$ immediately prior to setting up the hybridisation. Labelled cRNA was hybridised to the arrays under LifterSlips (Erie Scientific Company, Portsmouth, NH, USA) in GeneMachines HybChambers (Genomic Solutions Ltd, Cambridgeshire, UK) immersed in a $42{ }^{\circ} \mathrm{C}$ water bath for $16 \mathrm{~h}$.

The LifterSlips were removed by immersing slides in $2 \times \mathrm{SSC}, 0 \cdot 1 \%$ SDS, and the slides were placed subsequently in a slide rack immersed in $2 \times \mathrm{SSC}$, $0 \cdot 1 \%$ SDS. All post-hybridisation washes were performed on a shaker to ensure gentle agitation of the wash solution. Slides were washed twice in $2 \times \mathrm{SSC}$, $0 \cdot 1 \%$ SDS at room temperature for $5 \mathrm{~min}$, twice in $0.5 \times$ SSC, $0 \cdot 1 \%$ SDS at $55^{\circ} \mathrm{C}$ for $15 \mathrm{~min}$, and finally a quick rinse in water immediately prior to drying with compressed air. Slides were scanned in an Axon 4000B scanner at a resolution of $5 \mu \mathrm{m} /$ pixel and image analysis was done in GenePix Pro 5 (Molecular Devices, Sunnyvale, CA, USA).

\section{Experimental setup}

The experiment was designed to analyse the expression of genes in dorsal pancreatic cells at two temporally separated stages of pancreas development. This was accomplished by comparing expression profiles of embryonic dorsal pancreas tissue from Ngn3 null mice with wild-type littermates at days 13 and 15 of embryonic development. The comparison of gene expression in mutant and wild-type pancreas was primarily expected to show genes that are lower expressed/missing in the mutant, as Ngn3 null mice have no endocrine pancreas tissue. From each developmental stage, five wild-type and five mutant samples were chosen, representing embryos from at least three different litters. Wild-type and mutant samples from the common stage of development were paired randomly and analysed in flipped colour. Probes were spotted in duplicate on each slide in a randomised (fixed) layout, effectively distributing the duplicate spots randomly over the slide.

\section{Data analysis}

Analysis of the microarray data was done using R-2.2.0 (R Development Core Team 2005) and Bioconductor 1.7 packages (Gentleman et al. 2004). The limma package (Smyth et al. 2005) was used for the normalisation and identification of differentially expressed transcripts essentially as described in the Limma User's Guide. The arrays were normalised by print-tip loess normalisation followed by between slide-scale normalisation. After averaging within slide duplicates, a linear model was fitted to the data and empirical Bayesian smoothing was applied to the standard errors and 
finally, the Benjamini and Hochberg procedure of controlling false-discovery rate (Benjamini \& Hochberg $1995)$ was used to adjust $P$-values and a false-discovery rate of 0.01 was chosen. The dye-swap replicates were treated as described in the user's guide. The AnnBuilder package (Zhang et al. 2003) was used to build annotation database for the LION array; GO, GOstats and Rgraphviz packages were used for GO analysis and construction of the GO graph.

\section{DNA constructs}

The mouse cDNA for Ngn3 was a gift from F Guillemot. Mouse cDNA for Irx1 was a gift from Dr Vincent M Christoffel, University of Amsterdam, Holland. The full-length mouse Irx2 was purchased as an IMAGE EST clone. The chicken Irx genes were purchased from MRC Gene Service, Cambridge, UK. For electroporation, the Ngn3 cDNA was subcloned into the pCAGGS-IRES-EGFP vector (a gift from Dr Anne Grapin-Botton). Restriction digests and sequencing confirmed the correct orientation and reading frames of the constructs. Plasmids were purified using Endofree Maxiprep system (Qiagen) according to manufacturer's instructions.

\section{In ovo endoderm electroporation}

This method was performed as described earlier (Grapin-Botton et al. 2001, Pedersen \& Heller 2005). After $72 \mathrm{~h}$, surviving embryos were recovered and fixed in fresh 4\% paraformaldehyde (PFA) in PBS overnight. Only highly electroporated embryos, as determined by the abundance of green fluorescent protein $\left(\mathrm{GFP}^{+}\right)$ cells in the embryos, were further processed. Embryos were embedded in OCT compound (Sakura Fineteck Europe, Zoeterwoude, The Netherlands) and frozen on dry ice and stored at $-80^{\circ} \mathrm{C}$ until sectioned.

\section{Immunocytochemistry and in situ hybridisation}

In situ hybridisations were performed on $10 \mu \mathrm{m}$ frozen sections with DIG-labelled antisense RNA probes for Irx1-5 created using the DIG RNA synthesis kit from Roche, following the manufacturer's instructions. Mouse cDNAs for Irx1-5 were a gift from Dr Vincent M Christoffel, University of Amsterdam, Holland. The chicken Irx genes were purchased from MRC Gene Service, Cambridge, UK. Probes were hybridised to the tissues at $68^{\circ} \mathrm{C}$ followed by an AP-conjugated anti-DIG antibody (Roche). Deposition of the Nitro-Blue Tetrazolium/5-Bromo-4-chloro-3-indolyl phosphate (NBT/BCIP) chromophore (Sigma) was catalysed in $100 \mathrm{mM}$ NaCL $1 \mathrm{ml} 1 \mathrm{M} 100 \mathrm{mM}$ Tris, $\mathrm{pH} 9,51 \mathrm{ml} 1 \mathrm{M}$ $50 \mathrm{mM}$ MgCL $1 \mathrm{ml}$ 0,5 M 0,1\% Tween $2010 \mu \mathrm{l} 100 \%$ (NTMT) buffer at $\mathrm{pH} 9 \cdot 5$ and fast red (Sigma) signals for the fluorescent in situs were developed in $0 \cdot 1 \mathrm{M}$ Tris (pH 8.2). Immunostaining reactions were performed after antigen retrieval by microwave treatment in $10 \mathrm{mM}$ sodium citrate $(\mathrm{pH} 6 \cdot 0)$. The primary antiserum was incubated overnight at $4{ }^{\circ} \mathrm{C}$. Immunoreactivity was visualised with a Tyramide Signal Amplification (TSA) kit (Perkin-Elmer Life Science, Wellesley, MA, USA) or with the Alexa-series of secondary antibodies (Molecular Probes)

\begin{tabular}{|c|c|c|c|}
\hline & Species & Dilution & Source \\
\hline \multicolumn{4}{|l|}{ Antigen } \\
\hline$P d x 1253$ & Rabbit & $1: 5000$ & $\begin{array}{l}\text { Joel Habener, } \\
\text { MGH, Boston, MA }\end{array}$ \\
\hline Pax6 & Rabbit & $1: 2000$ & $\begin{array}{l}\text { Babco, Richmond, } \\
\text { CA. }\end{array}$ \\
\hline $\mathrm{Nkx6} 6 \cdot 1$ & Rabbit & $1: 5000$ & Jensen et al. (1996) \\
\hline Ngn3 & Rabbit & $1: 1000$ & $\begin{array}{l}\text { Michael German, } \\
\text { UCSF }\end{array}$ \\
\hline ISL-1 & Rabbit & $1: 1000$ & $\begin{array}{l}\text { Helena Edlund, } \\
\text { Umeå, Sweden }\end{array}$ \\
\hline Insulin & Mouse & $1: 75$ & $\begin{array}{l}\text { Novo Nordisk A/S, } \\
\text { Denmark }\end{array}$ \\
\hline Insulin & Guinea Pig & $1: 200$ & $\begin{array}{l}\text { DAKO, Glostrup, } \\
\text { Denmark }\end{array}$ \\
\hline Glucagon & Mouse & $1: 50$ & $\begin{array}{l}\text { Novo Nordisk A/S, } \\
\text { Denmark }\end{array}$ \\
\hline PP & Rabbit & $1: 500$ & $\begin{array}{l}\text { DAKO, Glostrup, } \\
\text { Denmark }\end{array}$ \\
\hline Somatostatin & Mouse & $1: 10$ & $\begin{array}{l}\text { Novo Nordisk A/S, } \\
\text { Denmark }\end{array}$ \\
\hline Somatostatin & Rabbit & $1: 100$ & $\begin{array}{l}\text { DAKO, Glostrup, } \\
\text { Denmark }\end{array}$ \\
\hline Ghrelin & Goat & $1: 500$ & $\begin{array}{l}\text { Santa Cruz } \\
\text { Biotechnology, CA }\end{array}$ \\
\hline cMYC (A14) & Rabbit & $1: 80$ & $\begin{array}{l}\text { Santa Cruz } \\
\text { Biotechnology, } \\
\text { Santa Cruz, CA }\end{array}$ \\
\hline cMYC (9E10) & Mouse & $1: 50$ & $\begin{array}{l}\text { Santa Cruz } \\
\text { Biotechnology, } \\
\text { Santa Cruz, CA }\end{array}$ \\
\hline
\end{tabular}

\section{RT-PCR}

Quantitative reverse transcriptase (RT)-PCR was performed on an ABI Prism 7900HT Sequence Detection System (Applied Biosystems, Foster City, CA, USA) using Assays-on-Demand Gene Expression Products (Applied Biosystems). Assays for verification of microarray results were delivered in low-density arrays. Total RNA was reverse-transcribed using Reverse Transcriptase Reagents (Applied Biosystems) according to manufacturer's recommendations. Relative quantification of gene expression measured on low-density arrays was performed using the $\Delta \Delta C_{\mathrm{t}}$ method. Critical threshold $\left(C_{\mathrm{t}}\right)$ cycle is defined as the cycle in which the reporter signal crosses a given threshold. The $C_{\mathrm{t}}$-values were normalized to $18 \mathrm{~S}$ levels by subtracting the $18 \mathrm{~S} C_{\mathrm{t}}$ values resulting in $\Delta C_{\mathrm{t}}$ values. The $\Delta \Delta C_{\mathrm{t}}$ values were 
obtained by subtracting $\Delta C_{\mathrm{t}}$ values from mutant and wild type, resulting in a $\log _{2}$ ratio of target gene expression in mutant over wild type (equivalent to the $M$ value determined in the microarray data analysis). The following assays were ordered as low-density arrays: Mm00514341_m1 (Chga), Mm00517617_m1 (Cryba2), Mm00432448_m1 (Cdkn1a), Mm00484138_m1 (Cyp4b1), Mm00456190_m1 (Myt1), Mm00440465_g1 (Neurod2), Mm00440480_m1 (Nnat), Mm00499982_m1 (Pcdh21), Mm00485697_m1 (Resp18), Mm00803266_m1 (Rbp4), Mm00460511_m1 (Rhbdl4), Mm00460679_m1 (Sesn2), Mm00600526_m1 (Syt13), Mm00443220_m1 (Tcp11), Mm00451001_m1 (Tm4sf2), Mm00491265_m1 (2510004L01Rik), Mm00549967_m1 (C81234), Mm00731595_gH (Ins2), Mm00437606_s1 (Neurog3).

\section{Results}

\section{Microarray analysis of $\mathbf{N g n 3 - d e f i c i e n t ~ m i c e ~}$}

To examine the difference in transcriptomes of dorsal pancreas from wild-type and Ngn3-deficient mice, a spotted cDNA microarray comprising 20188 probes covering 12140 genes plus ESTs was used. The comparison was made at two different stages of pancreas development, allowing monitoring of largescale parallel gene expression at the beginning and end of the secondary transition. Total RNA was isolated from homozygous wild-type and mutant pancreata, and a single round of RNA amplification yielded sufficient material for microarray analysis of individual pancreas.
Spatial analysis of the foreground and background intensities obtained after image analysis of the hybridised arrays did not reveal any major flaws (data not shown; Petri et al. 2004). Data analysis was performed as described in 'Materials and methods' and resulted in identification of 504 transcripts showing differential expression between $\mathrm{Ngn3}$-deficient and wild-type mice at e13 and/or e15 (see Fig. 1). The MA plots show that many of the identified genes show only relatively small differences in expression levels $(|M|<1$ corresponding to less than twofold). Furthermore, the majority of genes show decreased expression levels in mutant mice compared to wild type. To identify genes that exhibited a robust difference between wild type and mutant, we defined an $M$ value cut-off corresponding to at least twofold difference. This filtering strategy reduced the list of genes to 52 showing significant difference at e13 and/or e15 (Table 1), all with decreased expression in Ngn3-deficient mice. Expression of several neuropeptide genes (Ghrl, Gip, Gal, Cck and Npy) as well as genes whose products are involved in hormone processing (Pcsk2, Pcsk1n, and 7B2) are lacking in the mutant mice. Multiple members of the granin family (Chga, Chgb, Scg3), which are known to be expressed in endocrine cells of the pancreas, displayed large differences between mutant and wild-type mice $(M<-2)$. Two members (Syt7 and Syt13) of the synaptotagmin family of vesicle proteins, which are believed to mediate calcium-dependent regulation of membrane trafficking (Yoshihara \& Montana 2004) and transthyretin, which has an important role in the plasma transport of thyroid hormone $\mathrm{T} 4$ and retinol
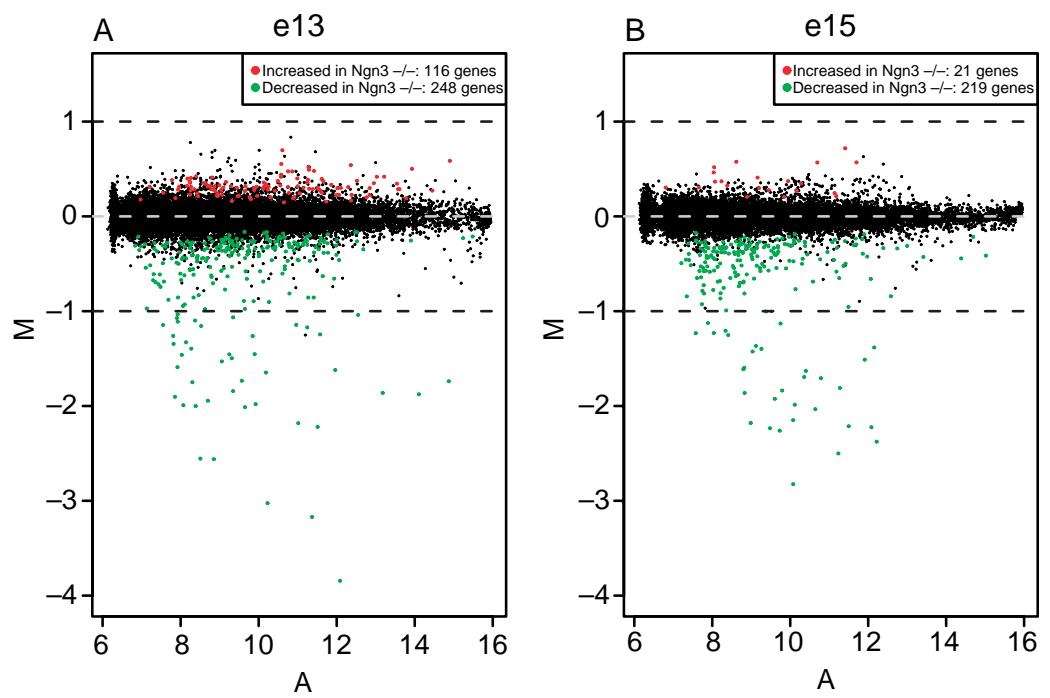

Figure 1 MA plots of microarray data from e13 (A) and e15 (B). (B). Transcripts showing significant difference between wild-type and Ngn3-deficient mice at a false discovery rate of $1 \%$ are emphasized with large coloured dots. Transcripts showing higher levels in wild type compared to mutant $(M>0)$ are red and transcripts showing lower levels $(M<0)$ are green. 
Table 1 List of genes showing robust difference in expression levels between Ngn3-deficient and wild-type mice at e13 or e15

Gene name

Symbol

e13.M

e13.Q.Value

e15.M

e15.Q.Value

Hormone, hormone processing

MG-8-92010 Galanin

MG-12-168g11 Gastric inhibitory polypeptide

MG-3-30i2 Ghrelin

$M G-6-55 p 2$

MG-6-22i12

MG-3-76n17

MG-14-40013

Binding

MG-6-3j21

MG-14-45h10

MG-6-55a14

MG-8-10104

MG-6-25p16

MG-16-118p10

Transcription, translation

MG-6-4c22

MG-6-27f14

MG-6-2g18

Transport

MG-6-64j8

MG-6-64b7

MG-8-12f2

$M G-14-119 n 19$

MG-11-1e9

Signalling

MG-6-36e16

MG-8-89p12

MG-6-30c20

Kinase/phosphatase

MG-6-15i10

MG-12-165c14

MG-14-3k11

MG-6-47c24

MG-6-67o19

Not classified

MG-19-1k5

MG-6-16l16

MG-12-140m7

MG-8-72n2

MG-60-1p11

MG-6-38n22

MG-3-89b2

EST

MG-6-60f22
Neuropeptide $Y$

Proprotein convertase subtilisin/kexin type 1 inhibitor

Proprotein convertase subtilisin/kexin type 2

Secretory granule neuroendocrine protein 1, 7B2 protein

Chromogranin A

Chromogranin B

Secretogranin III

Retinol binding protein 4, plasma

Secretagogin, EF-hand calcium binding protein

Protocadherin 21

Iroquois related homeobox 1 (Drosophila)

Myelin transcription factor 1

Ribosomal protein $\mathrm{S} 12$

$\begin{array}{ll}\text { Cck } & -2.18 \\ \text { Gal } & -1.40 \\ \text { Gip } & -1.26 \\ \text { MGl:1930008 } & -2.56 \\ \text { Npy } & -0.94 \\ \text { Pcsk1n } & -1.84 \\ \text { Pcsk2 } & -2.22 \\ \text { Sgne1 } & -1.26 \\ \text { Chga } & -3.02 \\ \text { Chgb } & -3.17 \\ \text { Scg3 } & -1.98 \\ \text { Rbp4 } & -1.62 \\ \text { Scgn } & -1.99 \\ \text { Pcdh21 } & -0.97\end{array}$

Irx1

Rps12

$-1 \cdot 03$

Synaptotagmin 7

Synaptotagmin 7

Synaptotagmin 13

Transthyretin

Transthyretin

Rhomboid, veinlet-like 4 (Drosophila)

GNAS (guanine nucleotide binding protein, alpha stimulating) Gnas

complex locus

Protein phosphatase 1, regulatory (inhibitor) subunit $1 \mathrm{~A}$

Ribosomal protein S6 kinase, polypeptide 4

Serum/glucocorticoid regulated kinase 2

Cyclin-dependent kinase inhibitor 1A (P21)

Protein tyrosine phosphatase, receptor type, N

Proviral integration site 2

Ureidopropionase, beta

Nucleosome assembly protein 1-like 5

Serine protease inhibitor, Kazal type 3

Fibrinogen, B beta polypeptide

Crystallin, beta A2

Regulated endocrine-specific protein 18

Solute carrier family 38 , member 5

RIKEN cDNA $1700012 \mathrm{H} 17$ gene

Ttr -1.73

$\begin{array}{ll}\text { Syt7 } & -0.67 \\ \text { Syt7 } & -0.90 \\ \text { Syt13 } & -1.65\end{array}$

Ttr -1.74

$-0.98$

$-1.90$

Ppp1r1a

$-0 \cdot 83$

Rps6ka4 $\quad-1.17$

Cdkn1a $\quad-1.14$

Ptprn $\quad-1.46$

Pim2

$-1.07$

Upb1

Nap115

Spink3

$-1 \cdot 16$

$-1 \cdot 75$

$-1.53$

Fgb

Cryba2

Resp18

$-1.33$

$-0 \cdot 74$

-1.59
-3.84

1700012H17Rik $\quad-1.86$
Sgk2 -1.07
$3.19 \times 10^{-9}$
$5.34 \times 10^{-7}$
$1.28 \times 10^{-4}$
$1.23 \times 10^{-7}$
$3.45 \times 10^{-4}$
$7.25 \times 10^{-7}$
$4.34 \times 10^{-7}$
$2.52 \times 10^{-7}$
$1.07 \times 10^{-9}$
$7.47 \times 10^{-8}$
$3.72 \times 10^{-7}$
$6.37 \times 10^{-7}$
$4.07 \times 10^{-6}$
$2.77 \times 10^{-4}$

$-1.99$

$-0.57$

$-0.55$

$-2 \cdot 23$

$-2 \cdot 26$
$-1 \cdot 37$

$-1 \cdot 37$

$-2 \cdot 22$
$-1 \cdot 69$

$-2 \cdot 50$

$-2 \cdot 38$

$-2 \cdot 03$

$-1.51$

$-2 \cdot 15$

$-1 \cdot 23$

$2.39 \times 10^{-7}-0.78$

$1.32 \times 10^{-5}-1.21$

$3.31 \times 10^{-8}-1.38$

$5.84 \times 10^{-5}-1.25$

$5.34 \times 10^{-7} \quad-1.40$

$3.68 \times 10^{-6}-1.71$

$4.07 \times 10^{-6} \quad-0.41$

$2.35 \times 10^{-4}-1.00$

$1.15 \times 10^{-7}-2 \cdot 18$

$3.72 \times 10^{-7}-1.60$

$8.45 \times 10^{-6}-0.25$

$3.68 \times 10^{-6}-0.38$

$2.14 \times 10^{-4} \quad-0.33$

$6.80 \times 10^{-6}-0.55$

$9.83 \times 10^{-6}-1.13$

$1.53 \times 10^{-6}-0.52$

$1.79 \times 10^{-6} \quad-0.69$

$1.76 \times 10^{-4}-0.53$

$3.20 \times 10^{-3}-0.28$

$1.76 \times 10^{-4}-1.61$

$1.37 \times 10^{-7}-1.23$

$1.15 \times 10^{-7}-2.21$

$7.72 \times 10^{-7} \quad-0.43$
$6.57 \times 10^{-7}-0.40$
$9.32 \times 10^{-6}$

$3.10 \times 10^{-4}$

$1.96 \times 10^{-8}$

$1.16 \times 10^{-8}$

$4.66 \times 10^{-9}$

$9 \cdot 20 \times 10^{-8}$

$2 \cdot 21 \times 10^{-8}$

$2.21 \times 10^{-8}$

$1.18 \times 10^{-8}$

$6.61 \times 10^{-8}$

$4.00 \times 10^{-9}$

$2.45 \times 10^{-8}$

$2.41 \times 10^{-7}$

$2.28 \times 10^{-5}$

$2.21 \times 10^{-8}$

$4.37 \times 10^{-8}$

$5.59 \times 10^{-10}$

$5.59 \times 10^{-10}$

$8.88 \times 10^{-9}$

$7.86 \times 10^{-4}$

$4.44 \times 10^{-4}$

$2.56 \times 10^{-8}$ $2.21 \times 10^{-8}$

$4.23 \times 10^{-8}$

$9.39 \times 10^{-3}$

$2.03 \times 10^{-2}$

$2.02 \times 10^{-3}$

$4.16 \times 10^{-5}$

$5.08 \times 10^{-9}$

$4.92 \times 10^{-5}$

$5.24 \times 10^{-6}$

$1.76 \times 10^{-1}$

$1.03 \times 10^{-1}$

$1.89 \times 10^{-8}$

$2.16 \times 10^{-7}$

$2 \cdot 79 \times 10^{-9}$

$1.08 \times 10^{-3}$
$3.21 \times 10^{-7}$ 
m人 t 으응으으으으으응으으으응으으 $\times \times \times \times \times \times \times \times \times \times \times \times \times$

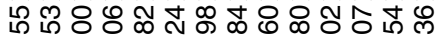

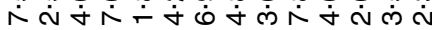

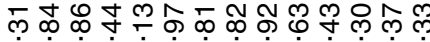

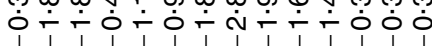
N 으응으으은으은으은으으응으으 $\times \times \times \times \times \times \times \times \times \times \times \times \times \times$

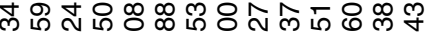

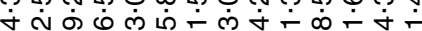

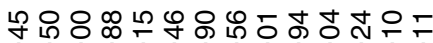

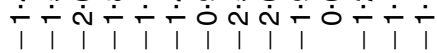
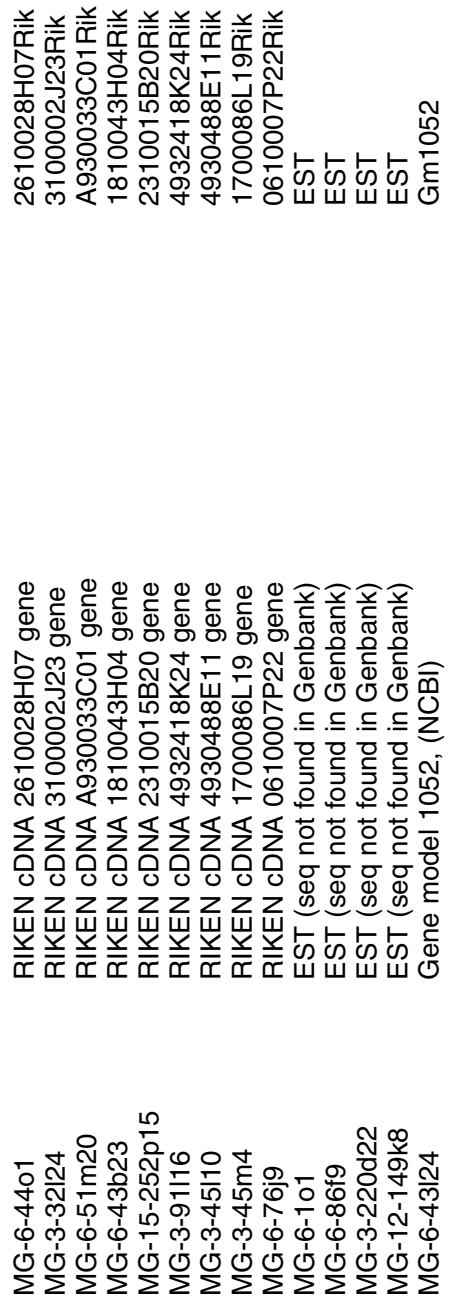

(Soares et al. 2003) are expressed at decreased levels in the mutant. Several genes encoding proteins involved in phosphorylation reactions are showing robust differences between mutant and wild type. Expression of genes involved in signalling pathways is also affected by Ngn3 deficiency. Rhomboid veinlet-like 4, a vertebrate homologue of Drosophila Rhomboid (Jaszai \& Brand 2002) encoding a protein involved in regulated intramembrane proteolysis, as well as Stimulatory G protein alpha subunit, are expressed at lower levels in mutant mice. Several ESTs and transcripts of genes with unknown function (RIKEN clones) are found at lower levels in dorsal pancreas from mutant mice, some of which show large differences. Interestingly, in this list of robustly differentially expressed transcripts, we detect two transcription factors, namely $M y t 1$, which was recently reported to be expressed in endocrine precursor cells (Gu et al. 2004) and Iroquois related homeobox 1 (Irx1). Irx1 belongs to a family of homeodomain proteins, which is conserved from nematodes to humans (Cavodeassi $e t$ al. 2001). Six different Irx genes have been identified in mouse, of which Irx 1, Irx 3 and Irx 5 are present on the array, but differential expression between mutant and wild type is only detected for Irx 1 .

Differential expression of several transcripts showing lower expression in mutant mice was verified by RT-PCR on total RNA isolated from another batch of mice $(n=3)$. We verified the expression of a few genes showing more than twofold difference as well as some genes showing less than twofold difference in expression levels at either e13 or e15 (see Fig. 2). The data from these experiments have been summarised in Fig. 2 and the actual values are shown in Supplementary Table 1 (See Supplementary data at http://jme.endocrinology-journals.org/content/vol37/ issue2). The RT-PCR results corroborated the microarray data. Only Cyp4b1 shows disagreement between the two platforms at both e13 and e15, whereas Cdkn1a does so at e15.

\section{Further microarray data analysis}

The filtration of microarray data described in the previous section resulted in identification of genes showing significant and robust difference in expression between mutant and wild type. However, the genes presented in Table 1 represent only a small subset (52 out of 504 genes) of the transcripts shown by microarray analysis to differ significantly between mutant and wild type at e13 and/or e15. The complete list of genes can be found in Supplementary Tables 2 and 3 (e13 and e15 data respectively: See Supplementary data at http://jme. endocrinology-journals.org/content/vol37/issue2). In particular, the additional filtration results in omission of a substantial fraction of genes showing increased expression, albeit small, at e13 (Fig. 1, red dots). The full sets of genes identified at e13 and e 15 were divided 

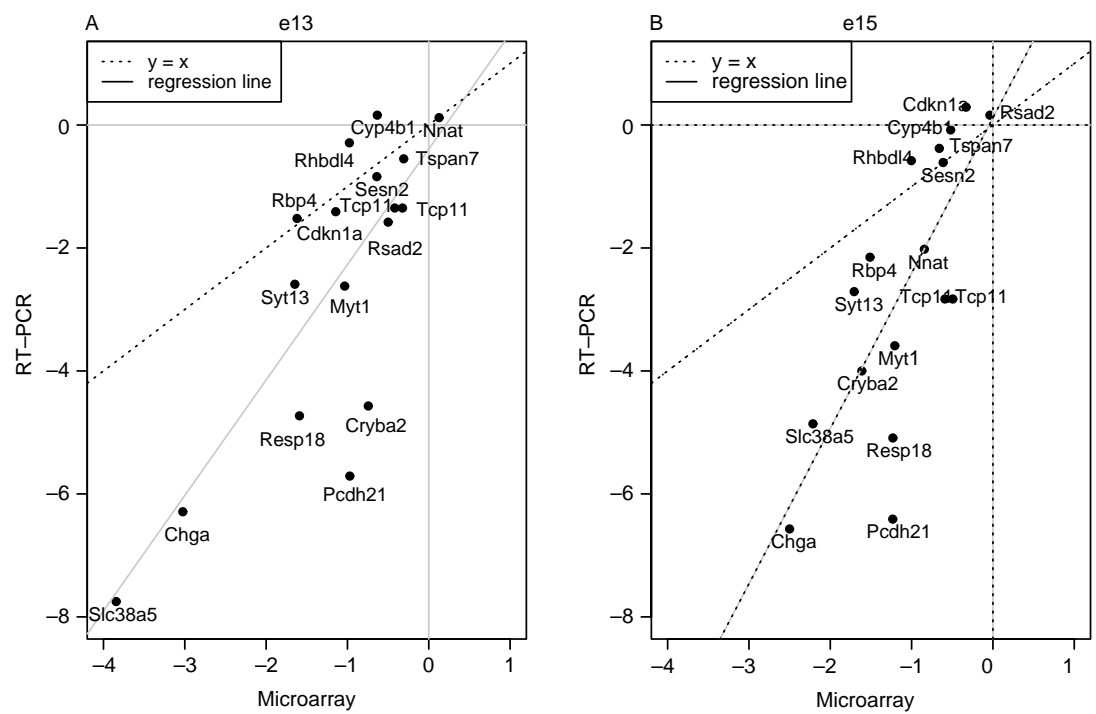

Figure 2 RT-PCR verification of selected gene expression differences. The scatter plots show the correlation between $\log _{2}$ fold differences determined by microarray analysis $(M$ values) and RT-PCR $\left(\Delta \Delta C_{\mathrm{t}}\right)$ at $\mathrm{e} 13$ and $\mathrm{e} 15$ for 16 genes. There is a positive correlation between the two platforms with $R^{2}$ values of 0.62 and 0.58 at e13 and e15 respectively. Inconsistencies were observed for Cyb4b1 at both e13 and e15, and for Cdkn1a at e15.

into groups of genes showing increased or decreased expression in the mutant. Subsequently, these gene lists were analysed for over-representation of gene ontology (GO) terms in the biological process (BP) branch of the ontology (see Table 2). The number of genes showing increased expression at e15 is quite small, not many terms are identified and those identified contain few genes. However, the other groups of genes show several notable terms. Not surprisingly, we find 'peptide hormone processing' and 'neuropeptide-signalling pathway' represented by genes showing decreased expression in the mutant at both e13 and e15. At e15, we further identify genes involved in 'transport' and 'G-protein-coupled receptor protein-signalling pathway' in the group of genes showing reduced expression. The most significant finding at e13 among decreased transcripts is terms related to tetrahydrobiopterin biosynthesis. Tetrahydrobiopterin is an obligatory co-factor of nitric oxide synthases (Kwon et al. 1989, Tayeh \& Marletta 1989) and in vitro experiments in INS-1 cells have shown that tetrahydrobiopterin synthesis precedes nitric oxidedependent inhibition of insulin secretion (Laffranchi $e t$ al. 1997). The terms that are associated with the largest number of genes showing reduced expression at e13 are related to apoptosis. Interestingly, genes involved in 'cell communication' and 'cell adhesion' show increased expression in the mutant at e13 and there is also an over-representation of genes involved in 'neurogenesis'. To further compare the difference between increased and decreased genes at e13, we computed the induced GO graph of genes identified at e13 and used a green-blackred colour gradient to indicate whether genes annotated at a particular node (either directly or by inheritance) showed increased expression, decreased expression, or a mix of both (Fig. 3 and Supplementary Figure S1 See Supplementary data at http://jme.endocrinology-journals.org/content/vol37/issue2). GO terms that were identified as significantly over-represented (Table 2) have been emphasized in Fig. 3. While only few terms are identified as significantly over-represented, this graph identifies processes, which are only affected by decreasing gene expression. Some of these terms have been labelled in Fig. 3.

\section{$\alpha$-Cell-specific Irx1/2 expression depend on and is induced by NGN3}

Irx 1 and Irx 2 have previously been shown to be expressed in the pancreas (Houweling et al. 2001) but their function and cell-specific expression pattern are unknown. Our microarray data suggest that Irx1 is expressed in the endocrine lineage. To determine whether Irx 1 and Irx2 were expressed in mature endocrine cells or their precursors, we performed fluorescent in situ hybridisations for the $\operatorname{Irx} 1 / 2$ genes followed by immunofluorescent stainings with a marker specific for these two populations. Irx 1- and Irx2expressing cells were found to be ISL1 ${ }^{+}$(Fig. 4A and C), a marker of mature endocrine cells (Thor et al. 1991, Ahlgren et al. 1997), but negative for the precursor marker NGN3 (Gradwohl et al. 2000, Jensen et al. 2000a, Schwitzgebel et al. 2000, Gu et al. 2002) although Irx1/2-expressing cells were often found in close association with $\mathrm{NGN3}^{+}$cells (Fig. $4 \mathrm{~B}$ and D). 
Table 2 Over-represented GO BP terms

Term

GO id

Over-represented Gene Ontology terms, e13 decreased expression

GO:0046146

GO:0006729

GO:0042559

GO:0042558

GO:0019438

GO:0016486

GO:0008219

GO:0016265

GO:0043064

GO:0007218

GO:0000082

GO:0006915

GO:0012501

GO:0007585

GO:0006558

Over-represente

GO:0009880

GO:0007224

GO:0009953

GO:0007389

GO:0007399

GO:0007420

GO:0009799

GO:0009855

GO:0007368

GO:0000059

GO:0007155

GO:0007417

GO:0007154

Over-represente

GO:0006816

GO:0016486

GO:0007017

GO:0015674

GO:0006810

GO:0042445

GO:0006812

GO:0016485

GO:0030001

GO:0007186

GO:0006811

GO:0007026

Over-represe

GO:0016049

GO:0008361

GO:0040007
Tetrahydrobiopterin metabolism

Tetrahydrobiopterin biosynthesis

Pteridine and derivative biosynthesis

Pteridine and derivative metabolism

Aromatic compound biosynthesis

Peptide hormone processing

Cell death

Death

Flagellum organization and biogenesis

Neuropeptide-signalling pathway

G1/S transition of mitotic cell cycle

Apoptosis

Programmed cell death

Respiratory gaseous exchange

L-phenylalanine metabolism

creased expression

Embryonic pattern specification

Smoothened receptor-signalling pathway

Dorsal/ventral pattern formation

Pattern specification

Neurogenesis

Brain development

Determination of symmetry

Determination of bilateral symmetry

Determination of left/right symmetry

Protein-nucleus import, docking

Cell adhesion

Central nervous system development

Cell communication

creased expression

Calcium ion transport

Peptide hormone processing

Microtubule-based process

Di-, tri-valent inorganic cation transport

Transport

Hormone metabolism

Cation transport

Protein processing

Metal ion transport

G-protein-coupled receptor protein-signalling

pathway

Ion transport

Microtubule stabilisation

reased expression

Cell growth

Regulation of cell size

Growth
Genes

$P$ value

$7.02 \times 10^{-5}$

$7.02 \times 10^{-5}$

$5.56 \times 10^{-4}$

$7 \cdot 84 \times 10^{-4}$

$1.06 \times 10^{-3}$

$3.62 \times 10^{-3}$

$4.15 \times 10^{-3}$

$4.69 \times 10^{-3}$

$5.36 \times 10^{-3}$

$5.52 \times 10^{-3}$

$5.57 \times 10^{-3}$

$6.68 \times 10^{-3}$

$7.10 \times 10^{-3}$

$9.76 \times 10^{-3}$

$9.76 \times 10^{-3}$

$3.01 \times 10^{-4}$

$1.61 \times 10^{-3}$

$1.61 \times 10^{-3}$

$1.83 \times 10^{-3}$

$3.23 \times 10^{-3}$

$4.52 \times 10^{-3}$

$4.70 \times 10^{-3}$

$4.70 \times 10^{-3}$

$4.70 \times 10^{-3}$

$5.71 \times 10^{-3}$

$5.97 \times 10^{-3}$

$6.31 \times 10^{-3}$

$7.51 \times 10^{-3}$

$3.02 \times 10^{-6}$

$5.63 \times 10^{-5}$

$7.93 \times 10^{-5}$

$8.10 \times 10^{-5}$

$4.44 \times 10^{-4}$

$1.49 \times 10^{-3}$

$1.62 \times 10^{-3}$

$2.24 \times 10^{-3}$

$2.55 \times 10^{-3}$

$3.34 \times 10^{-3}$

$5.09 \times 10^{-3}$

$8.47 \times 10^{-3}$

$2.94 \times 10^{-3}$

$3.21 \times 10^{-3}$

$5 \cdot 88 \times 10^{-3}$
To determine if $\operatorname{Irx} 1 / 2$ gene expression was restricted to a particular endocrine subtype, we performed in situ hybridisation for $\operatorname{Irx} 1 / 2$ (Fig. 5A and F) followed by fluorescent antibody staining for the major pancreatic hormones. We found Irx 1 and Irx 2 to be co-expressed with glucagon (Fig. 5D and I), but not insulin (Fig. 5C and $\mathrm{H}$ ) and somatostatin at e 18 (Fig. $5 \mathrm{E}$ and $\mathrm{J}$ ). Irx $1 / 2$ did co-localize with a subpopulation of PP cells, most of which also expressed glucagon (data not shown). The $\alpha$-cell-specific expression of Irx1/2 was also seen in E4 chicken pancreas (Fig. 5A-D). Additionally, RT-PCR analysis demonstrated prominent Irx $1 / 2$ expression in the mouse glucagonoma cell line, $\alpha \mathrm{TC1} \cdot 9$ (Hamaguchi \& Leiter 1990) while the insulinoma cell line $\beta$ TC3 (Efrat et al. 1988) had barely detectable levels (data not shown).

Consistent with our microarray data, expression of Irx1/2 was lost in mice deficient in $\mathrm{Ngn3}$ (Fig. 6A-D). Furthermore, forced expression of NGN3 in chick endoderm induced the expression of both Irx1 (data 


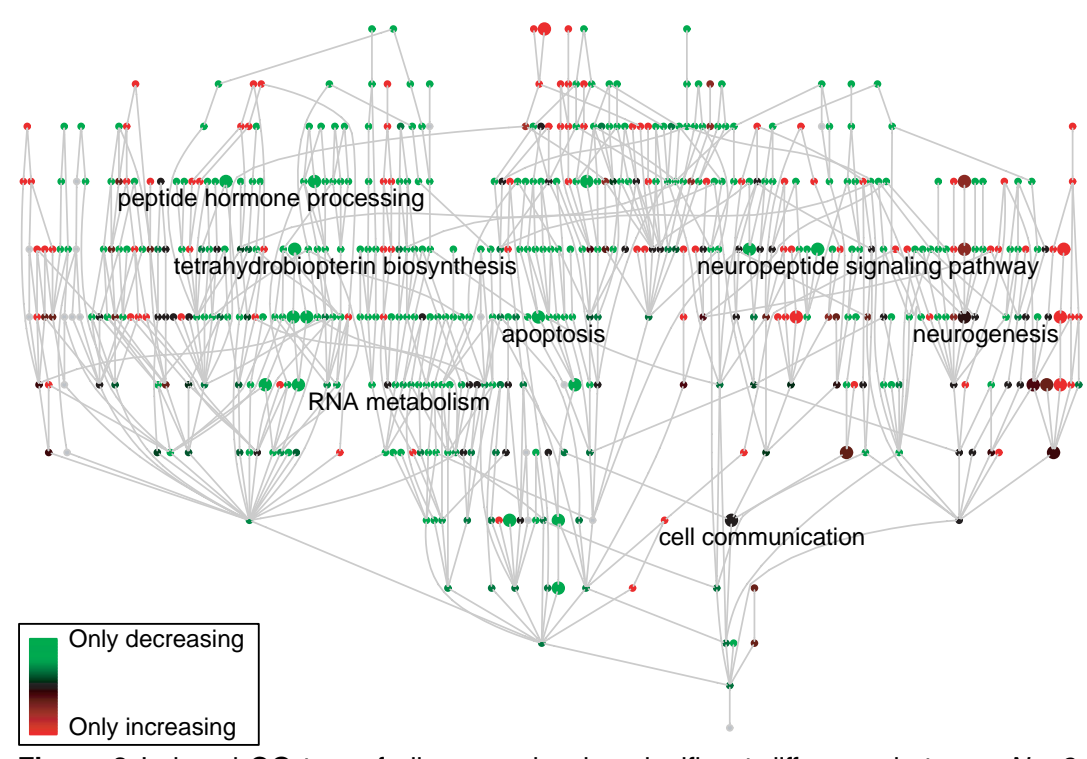

Figure 3 Induced GO tree of all genes showing significant difference between Ngn3deficient and wild-type mice. Each node in the tree corresponds to a particular GO term, which might be child to one or more GO terms and in turn be parent to the same. The root of the GO tree corresponds to very generic terms and progressing upwards from parent term to child term results in increasingly more specific GO terms. Some nodes in this induced GO graph are not represented by probes on the chip and these have been coloured grey.

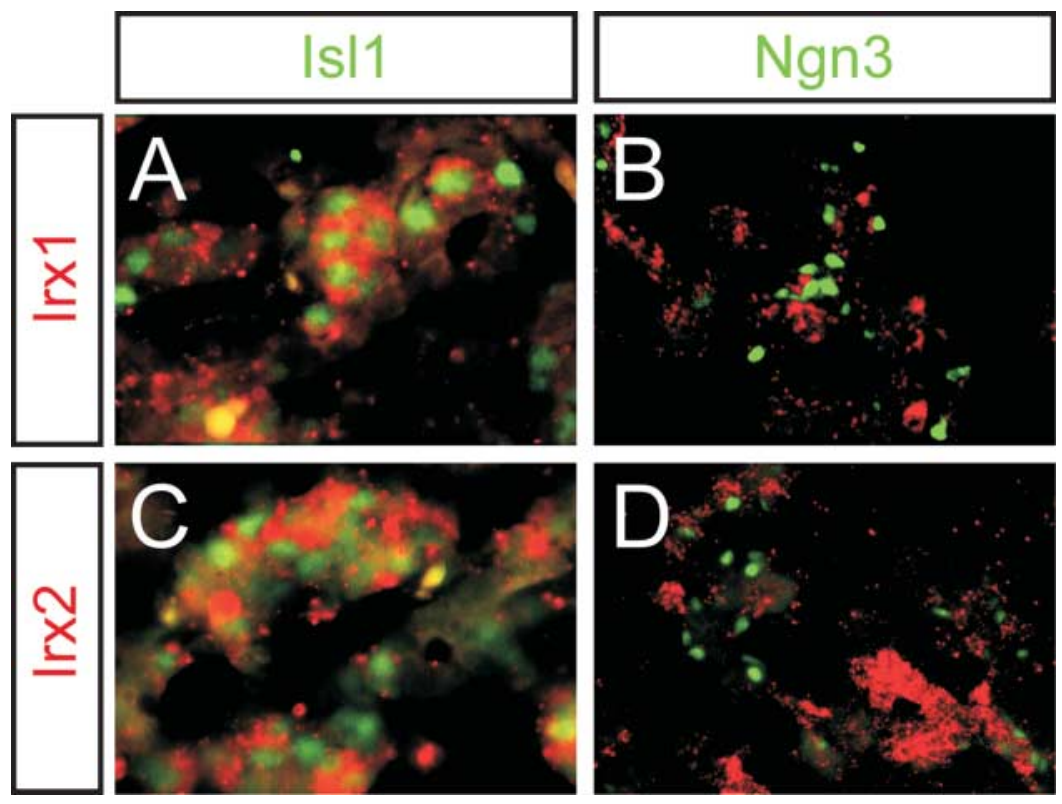

Figure 4 Irx1- and Irx2-expressing cells belong to the endocrine lineage (A-D) Localisation of Irx1 and Irx2 with ISL1 and NGN3 at e16 visualised by fluorescent in situ hybridisations for Irx1 and Irx2 (in red) followed by immunofluorescent stainings for NGN3 and ISL1 (in green). ISL1 is detectable in Irx1- (A) and Irx2- (C) positive cell clusters showing their endocrine nature. $(B, D)$ Some NGN3-positive endocrine precursors lie close to Irx1- and Irx2-expressing cells. A and $\mathrm{C}$ are $100 \times$ magnification. $B$ and $D$ are $250 \times$ magnification. 


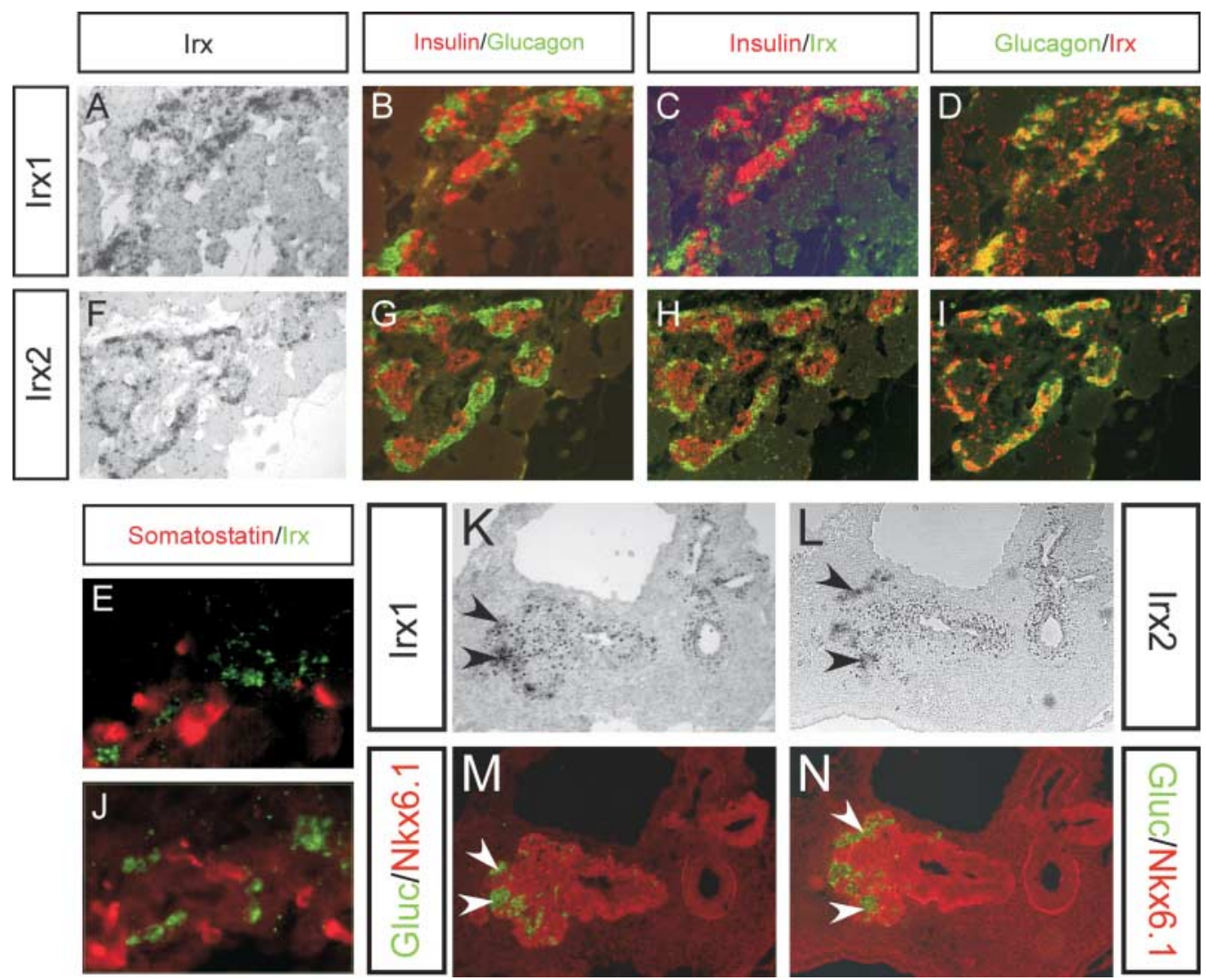

Figure 5 Irx 1 and Irx2 are expressed in the $\alpha$-cells but not in $\beta$-cells or $\delta$-cells. (A-N). In situ hybridisation at e18 for Irx1 and Irx2 as indicated combined with double immunofluorescent stainings for insulin and glucagon (A-D and $\mathrm{F}-\mathrm{I}$ ) or immunofluorescent stainings for somatostatin (E and $\mathrm{J}$ ). $\mathrm{B}$ and $\mathrm{G}$ show the emerging islets with insulin immunoreactive cells in the core and glucagon immunoreactive cells at the periphery. $\mathrm{C}$ and $\mathrm{H}$ show merged images of glucagon and Irx1 and Irx2 respectively. D and I show merged images of insulin and Irx1 and Irx2 respectively. Note that Irx1 and Irx2 are co-expressed with glucagon but not with insulin. E and J show that Irx1- and Irx2-positive cells respectively, do not express somatostatin. (Irx is shown in false colour in C-E and $\mathrm{H}-\mathrm{J}$ ). In situ hybridisation for the chicken Irx1 and Irx2 genes followed by immunocytochemistry for Nkx6.1 and glucagon on the same sections of E4 chick embryos (K-N) Irx1 and Irx2 are expressed in the pancreatic area (black arrowheads) where the glucagon cells (white arrowheads) are expressed. Nkx6.1 is used as a marker for the pancreatic region. Small black dots in panels $\mathrm{A}$ and $\mathrm{B}$ are small bubbles and an artefact of the in situ hybridisation procedure.

not shown) and Irx2 and a subset of the Ngn3/Irx positive cell clusters were also glucagon immunoreactive (Fig. 6E-H).

\section{Discussion}

The microarray experiment described here was set up to analyse changes in gene expression in the pancreas of $\mathrm{Ngn3}$-deficient mice. Owing to the absence of $\mathrm{Ngn} 3$, cells of the developing pancreas cannot adopt an endocrine cell fate resulting in mice lacking endocrine pancreatic cells (Gradwohl et al. 2000). The transcription profiling was done on spotted cDNA microarrays containing 20188 probes from LION Bioscience's murine arrayTAG set. A large fraction of the clones in the murine LION clone set were derived from tissues such as brain, testis, embryos and embryonic stem cells, but not pancreas. Therefore, several pancreas-related genes including insulin, glucagon, Ngn3, Pdx1, NeuroD, Isl1 and Pax4 are not present on the array. Nonetheless, due to the many similarities between pancreatic endocrine cells and neuronal cells, both in terms of developmental mechanisms and expressed genes (Slack 1995, Wilson 2003), the murine arrayTAG clone collection is well suited for the analysis of gene expression in pancreas lacking endocrine cells. Initially, we analysed the data to find genes showing significant and more than twofold difference between mutant and wild type at e13 and/or e15. This strict filtering 


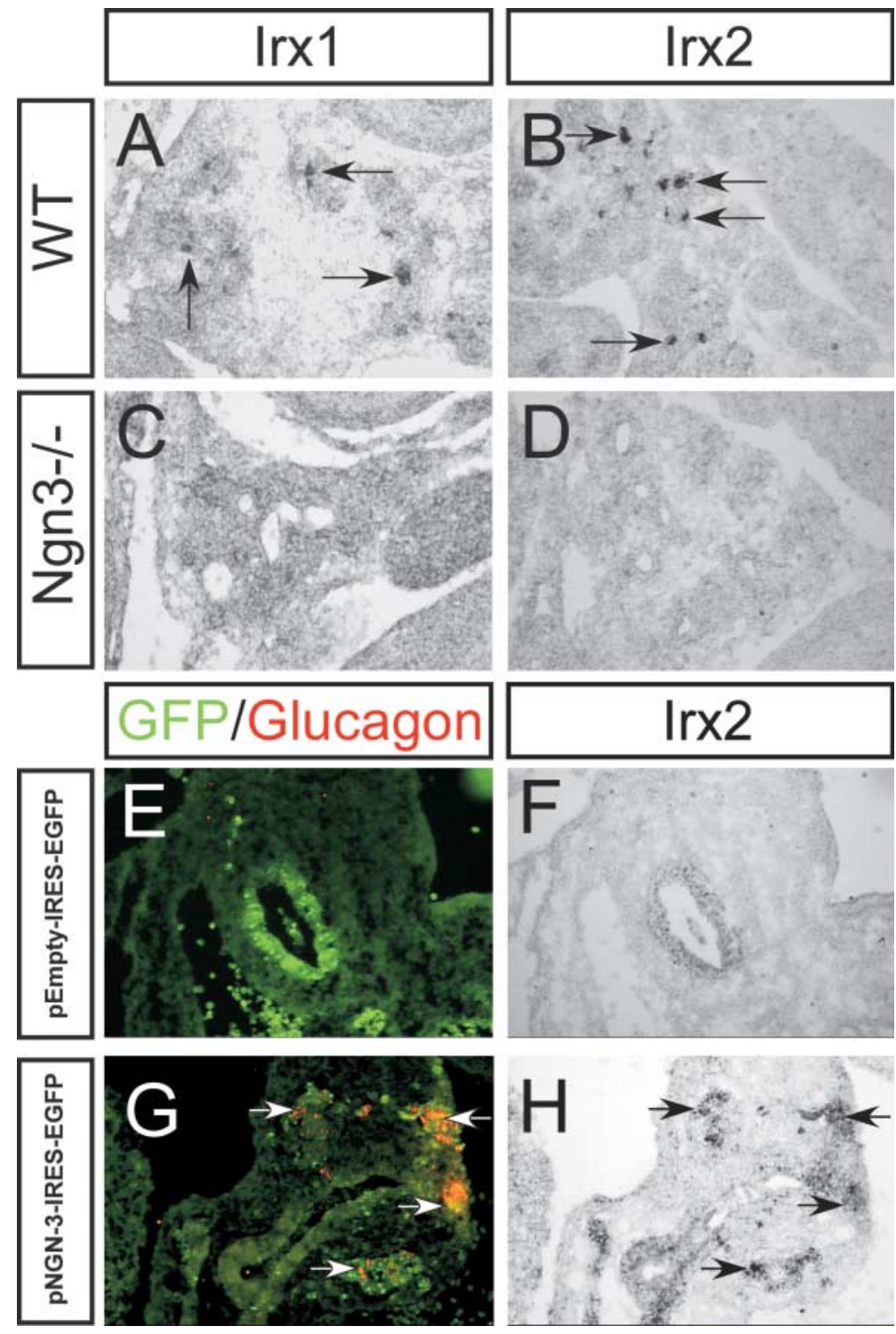

Figure 6 Irx1- and Irx2-expressing cells belong to the endocrine lineage and can be induced by exogenous Ngn3. (A-D) Irx1 and Irx2 expression in e14 wild-type (WT) and Ngn3-deficient ( $\mathrm{Ngn}^{-1-}$ ) pancreata visualised by in situ hybridisation. (A-B) Irx1 and Irx2 are expressed in a characteristic pattern resembling endocrine cell clusters, which mainly consist of $\alpha$-cells at this time point and specific expression is denoted by arrows (C and D). The expression of Irx1 and Irx2 is lost in the Ngn3 KO demonstrating that these genes are expressed in the endocrine lineage. Black arrows denote areas of Irx expression, while white arrows depict areas with glucagon-expressing cells. Asterisks denote autofluorescent red blood cells. $(E-H)$ Expression of Ngn3 in chicken endoderm induces the expression of Irx2. (E) Expression of the pEMPTY-IRES-EGFP plasmid does not induce Irx2 expression $(F)$, while expression of pNgn-3-IRES-EGFP $(G)$ induces glucagon and Irx2 expression $(\mathrm{H})$. White and black arrows denote the areas on the section where glucagon and Irx2 are expressed in the same area. A-D, F, and $\mathrm{H}$ are $100 \times$ magnification. $\mathrm{E}$ and $\mathrm{G}$ are $250 \times$ magnification.

approach resulted in identification of a small set of 52 genes, all showing lower transcription levels in mutant compared to wild-type mice (see Fig. 1 and Table 1). The simplest explanation for the reduced level of transcription of these genes in the mutant is that they are normally expressed in the endocrine lineage of the pancreas and due to the lack of this lineage in Ngn3deficient mice, the transcript levels compared to wild 
type appear lower. Indeed, many of the genes in Table 1 are known from the literature to be expressed in the endocrine lineage (Npy (Ding et al. 1997), Ghrl (Wierup et al. 2002, Prado et al. 2004, Heller et al. 2005), Pcsk1n (Guest et al. 2002), Pcsk2 (Furuta et al. 1997), Myt1 (Gu et al. 2004), Chga, Chgb (Karlsson 2001), Scg3 (Sakai et al. 2004), Cdkn1a (Kaneto et al. 1999)). However, several genes in Table 1 have not yet been described in pancreas biology. Rhomboid, veinlet-like 4 is a vertebrate homolog of Drosophila Rhomboid. In Drosophila, Rhomboid-1 is a key regulator of EGF-receptor signalling (Bier et al. 1990), controlling cleavage of the membrane-bound EGF-receptor ligand Spitz. The components of EGFR signalling are ubiquitously expressed during Drosophila development, whereas the rhomboid proteases are not and the regulated intramembrane cleavage of Spitz by Rhomboid is thus the primary mechanism for controlling EGFR signalling in developing Drosophila embryos (Rutledge et al. 1992, Urban et al. 2002). Interestingly, EGF pathway components are expressed in the developing pancreas in mice (Miettinen et al. 2000) and Erbb1 as well as Erbb2 is required for normal endocrine pancreas development (Miettinen et al. 2000, Huotari et al. 2002). Further studies are needed to determine the location and function of Rhomboid, veinlet-like 4 in endocrine pancreas development. Additionally, many ESTs and genes encoding proteins with unknown functions were identified in our analysis. Some of the ESTs identified in this experiment do not have sequence homology to any sequences in GenBank and since the sequences on this array are derived from the $3^{\prime}$ UTR, homology search might not reveal homology to known families of proteins with conserved motifs. RT-PCR verifications of microarray data showed good agreement between the two platforms (Fig. 2 and Supplementary Table 1; See Supplementary data at http://jme.endocrinologyjournals.org/content/vol37/issue2). Slight discrepancies were only observed for $C y p 4 b 1$ and Cdkn1a. BLAST analysis of the probe sequences for Cyp $4 b 1$ revealed that, in addition to Cyp4b1, the probe showed homology to a predicted gene similar to Cyp4b1 (CYPIVB1, XM_983069; data not shown). This suggests that the Cyp4b1 discrepancy between microarray and RT-PCR could be caused by cross-hybridisation. Cdkn1a data only show discrepancy at e15, where microarray data shows $0 \cdot 8$-fold reduction, while RT-PCR shows $1 \cdot 2$-fold increase in mutants. BLAST analysis of the Cdkn1a probe sequence did not show any unexpected hybridisation partners and discrepancy at only e15 suggests minor inaccuracies in one of the platforms. In a previous study of gene expression in pancreas, it was shown that Cdkn1a is enriched in Ngn3 + cells versus pancreatic tissue of other stages (Gu et al. 2004) which is in line with the microarray data presented here.
Several transcription factors (Myt1, Hes1, Hes6, MafB, Tcf2, Pax6 and Irx 1) show reduced expression in Ngn3 mutants compared to wild type and identification of some of these serve as positive control for the analysis. Previous studies have shown that Pax6 is expressed in all cells of the endocrine lineage and loss of this transcription factor leads to arrest of endocrine development prior to final differentiation (Sander et al. 1997, St Onge et al. 1997). Myt1 was recently identified by $\mathrm{Gu}$ et al. (2004) in a microarray experiment involving distinct populations of cells from different stages of pancreatic development. Myt1 was shown to be expressed in endocrine progenitor cells and the ability of Ngn3 to promote $\alpha$ - and $\beta$-cell development likely depends on Myt1 (Gu et al. 2004). The transcription factor, Irx1, belongs to a family of homeodomain proteins known as Iroquois and includes six members. The Irx family of transcription factors have been shown to be required early during development to define large territories, but also play a role later on for subdividing these domains (Cavodeassi et al. 2001). We confirmed and extended previous observations (Houweling et al. 2001, Lebel et al. 2003) showing that Irx1 and 2 but not 3, 4 and 5 (data not shown) are expressed in the pancreas. We demonstrate here that Irx 1 and Irx2 are specifically expressed in $\alpha$-cells. Furthermore, our data suggest that $\operatorname{Irx} 1$ and $\operatorname{Irx} 2$ could be operating at early stages of endocrine subtype specification soon after commitment to the endocrine lineage as Irx 1/2 was induced by NGN3 in many cells that did not yet express glucagon. The identical expression of the two Irx genes and their highly related homeodomains suggest that they might serve redundant functions during $\alpha$-cell development. It was recently demonstrated that MAP kinase-mediated phosphorylation can change Irx2 from a repressor to an activator in developing midbrain tissue (Matsumoto et al. 2004), but the transcriptional activity and function of Irx1/2 proteins in $\alpha$-cells is unknown. Further, gain- and loss-of-function experiments will be required to dissect the precise role of this family of transcription factors in the pancreas.

The MA plots in Fig. 1 show that genes exhibiting a significant difference in expression level of more than twofold between wild type and mutant constitute only a minor fraction of the significant results. In an attempt to provide an unbiased analysis of the microarray data, we carried out additional analysis based on all genes found to show statistically significant difference between the wild type and the mutant. The genes identified at e13 and e15 were divided into groups of genes showing increased expression and those showing decreased expression. For each of these groups of genes, we used the GOstats package to carry out a hypergeometric test to determine whether there was over-representation of genes at particular GO terms in the Biological Process branch of the ontology (Table 2). The genes showing decreased expression levels in the 
mutant might primarily be expected to be expressed in endocrine cells. While 'peptide-hormone processing' and 'neuropeptide signalling' are common to both e13 and e15, there are differences in the terms that are over-represented at the two stages of development. It is tempting to speculate that the difference in BP terms reflects that Ngn3 lineage cells at e13 and e15 are at different developmental stages. At e13, a large group of apoptosis-related genes are identified (Rnf130, Gadd45g, Cdkn1a, Btg2, Txnl1, Sphk1, 1700020C11Rik, Smndc1, Pim2, Unc5a and E2f2). While cell death has been demonstrated to be a common event in the development of several organs (Barres et al. 1992, Coles et al. 1993, Coucouvanis \& Martin 1995), nothing is known about the role of apoptosis in formation of the pancreas. Several negative regulators of apoptosis are identified (Pim2, Sphk1, Btg2, and Cdkn1a), which might indicate that suppression of apoptotic signals is necessary for proper development of endocrine cells. At e15, many of the genes showing decreased expression encode proteins involved in transport or 'G-protein-coupled receptor protein-signalling pathway'. It is well known that insulin secretion is triggered by $\mathrm{Ca}^{2+}$ influx through voltage-dependent $\mathrm{Ca}^{2+}$ channels (reviewed in (Mears 2004)) and recently G-protein-coupled receptor signalling has been shown to influence insulin secretion (Briscoe et al. 2003, Itoh et al. 2003). Thus both, 'transport' and offspring terms as well as 'G-protein-coupled receptor protein-signalling pathway' are reconcilable with a predominantly mature phenotype of the Ngn3-lineage cell at e15.

Interestingly, 116 probes on the array detect slightly increased expression levels in Ngn3-deficient mice at e13. It has been shown that Ngn3 is both required and sufficient for inducing endocrine differentiation in pancreatic cells (Gradwohl et al. 2000, Grapin-Botton et al. 2001); thus many genes showing increased expression in the mutant could suggest that the absence of endocrine and progenitor cells has an effect on parts of the remaining pancreatic cells. The fact that only 21 genes with increased expression are found at e15 could be caused by a dilution effect where cells that are potentially affected by the lack of endocrine progenitor or mature endocrine cells is outnumbered by non-endocrine cells which are more abundant at e15 than at e13. Among the genes showing increased expression in the mutant at e13, we identified GO terms 'neurogenesis', 'cell adhesion', and 'cell communication' as significantly over-represented. Whether these GO terms reflect some sort of compensatory mechanism or a response to lacking endocrine and precursor cells, requires further study.

The entire list of genes identified at e13 was used to compute the induced GO graph in the BP branch. Colour coding of this graph shows that there are biological processes that appear to be represented only in the list of increasing or decreasing genes. The group of genes showing decreased expression in the mutant is larger than those showing increased expression and consequently, there is a clear overweight of different shades of green. 'RNA metabolism' and offspring terms like 'nuclear mRNA splicing, via spliceosome' are only represented by genes showing decreased expression. In a recent paper, Gunton et al. (2005) presented microarray data showing that a group of RNA processing genes are significantly altered in islets from type-2 diabetic patients. Whether RNA processing plays a crucial role in endocrine cell development or function requires further analysis. The interactive version of the GO graph presented in the Supplementary Data (Figure S1; See Supplementary data at http://jme.endocrinology-journals.org/content/vol37/issue2) can be used to browse the data and give more detailed GO annotation of the genes identified at e13.

A few issues should be kept in mind when using GO annotations to summarise microarray results, as done in this paper. First, only $50 \%$ of the genes in the LION murine arrayTAG set have GO annotations and some of these are solely inferred from electronic annotation, meaning that no human judgement was used in the process. Secondly, the GO database is subject to constant change as our understanding of biology and biological processes changes meaning that redoing the analysis in the future will probably give slightly different results. Thirdly, the fact that development of the pancreas involves differentiation of several different cell types differentiating asynchronously, makes analysis of large gene lists difficult, and identification of multiple genes with similar GO annotations does not imply that the encoded proteins interact physically. Nevertheless, the use of GO terms provides an unbiased way of analysing large data sets like microarray data and importantly, brings together the combined knowledge from several different model organisms.

In conclusion, using advanced microarray technology and data mining, we have revealed Irx-1/2, as new pancreatic glucagon-producing cell-specific genes, whose function in the pancreas remains unknown. Additionally, our microarray data strongly suggest that the absence of Ngn3 positive and mature endocrine cells results in changes in gene expression in embryonic exocrine/ductal cells. GO-based analysis of genes showing reduced expression in the mutant and genes showing increased expression revealed multiple biological processes that are affected solely by increased or decreased gene expression, suggesting that these processes are involved in the development or the function of pancreatic cells or are important in the cross-talk between the formation of endocrine tissue and the other pancreatic cell types during development. 


\section{Acknowledgements}

The authors would like to thank Dr Nanni Din as well as Kirsten Brunstedt, Tine Pedersen and Anette Seneca for amplifying, purifying and printing the LION clone collection. We would like to thank Dr Gerard Gradwohl for valuable discussions. Furthermore, we would like to thank the R project and Bioconductor Consortium for contributing a splendid software solution for microarray data analysis. This work was made possible through support from JDRF and NIH (U19 DK072495-01, PS) and the Danish Research Council (AP). The authors declare that there is no conflict of interest that would prejudice the impartiality of this scientific work.

\section{References}

Ahlgren U, Pfaff SL, Jessell TM, Edlund T \& Edlund H 1997 Independent requirement for ISL1 in formation of pancreatic mesenchyme and islet cells. Nature 385 257-260.

Apelquist A, Li H, Sommer L, Beatus P, Anderson DJ, Honjo T, de Angelis MH, Lendahl U \& Edlund H 1999 Notch signalling controls pancreatic cell differentiation. Nature 400 877-881.

Barres BA, Hart IK, Coles HS, Burne JF, Voyvodic JT, Richardson WD \& Raff MC 1992 Cell death and control of cell survival in the oligodendrocyte lineage. Cell 70 31-46.

Benjamini Y \& Hochberg Y 1995 Controlling the false discovery rate: a practical and powerful approach to multiple testing. Journal of the Royal Statistical Society: Series B 57 289-300.

Bier E, Jan LY \& Jan YN 1990 Rhomboid, a gene required for dorsoventral axis establishment and peripheral nervous system development in Drosophila melanogaster. Genes and Development 4190 203.

Briscoe CP, Tadayyon M, Andrews JL, Benson WG, Chambers JK, Eilert MM, Ellis C, Elshourbagy NA, Goetz AS, Minnick DT et al. 2003 The orphan G protein-coupled receptor GPR40 is activated by medium and long chain fatty acids. Journal of Biological Chemistry 278 11303-11311.

Cavodeassi F, Modolell J \& Gomez-Skarmeta JL 2001 The Iroquois family of genes: from body building to neural patterning. Development 128 2847-2855.

Coles HS, Burne JF \& Raff MC 1993 Large-scale normal cell death in the developing rat kidney and its reduction by epidermal growth factor. Development 118 777-784.

Coucouvanis E \& Martin GR 1995 Signals for death and survival: a two-step mechanism for cavitation in the vertebrate embryo. Cell 83 279-287.

Ding WG, Kimura H, Fujimura M \& Fujimiya M 1997 Neuropeptide Y and peptide $\mathrm{YY}$ immunoreactivities in the pancreas of various vertebrates. Peptides 18 1523-1529.

Efrat S, Linde S, Kofod H, Spector D, Delannoy M, Grant S, Hanahan D \& Baekkeskov $S 1988$ Beta-cell lines derived from transgenic mice expressing a hybrid insulin gene-oncogene. PNAS 85 9037-9041.

Furuta M, Yano H, Zhou A, Rouille Y, Holst JJ, Carroll R, Ravazzola M, Orci L, Furuta H \& Steiner DF 1997 Defective prohormone processing and altered pancreatic islet morphology in mice lacking active SPC2. PNAS 94 6646-6651.

Gentleman RC, Carey VJ, Bates DM, Bolstad B, Dettling M, Dudoit S, Ellis B, Gautier L, Ge Y, Gentry J et al. 2004 Bioconductor: open software development for computational biology and bioinformatics. Genome Biology 5 R80.
Gradwohl G, Dierich A, LeMeur M \& Guillemot F 2000 Neurogenin3 is required for the development of the four endocrine cell lineages of the pancreas. PNAS 97 1607-1611.

Grapin-Botton A, Majithia AR \& Melton DA 2001 Key events of pancreas formation are triggered in gut endoderm by ectopic expression of pancreatic regulatory genes. Genes and Development 15 444-454.

Gu G, Dubauskaite J \& Melton DA 2002 Direct evidence for the pancreatic lineage: NGN3 + cells are islet progenitors and are distinct from duct progenitors. Development 129 2447-2457.

Gu G, Brown JR \& Melton DA 2003 Direct lineage tracing reveals the ontogeny of pancreatic cell fates during mouse embryogenesis. Mechanisms of Development 120 35-43.

Gu G, Wells JM, Dombkowski D, Preffer F, Aronow B \& Melton DA 2004 Global expression analysis of gene regulatory pathways during endocrine pancreatic development. Development 131 165-179.

Guest PC, Abdel-Halim SM, Gross DJ, Clark A, Poitout V, Amaria R, Ostenson CG \& Hutton JC 2002 Proinsulin processing in the diabetic Goto-Kakizaki rat. Journal of Endocrinology 175 637-647.

Gunton JE, Kulkarni RN, Yim S, Okada T, Hawthorne WJ, Tseng YH, Roberson RS, Ricordi C, O'Connell PJ, Gonzalez FJ et al. 2005 Loss of ARNT/HIFlbeta mediates altered gene expression and pancreatic-islet dysfunction in human type 2 diabetes. Cell 122 337-349.

Hamaguchi K \& Leiter EH 1990 Comparison of cytokine effects on mouse pancreatic alpha-cell and beta-cell lines. Viability, secretory function, and MHC antigen expression. Diabetes 39 $415-425$.

Heller RS, Jenny M, Collombat P, Mansouri A, Tomasetto C, Madsen OD, Mellitzer G, Gradwohl G \& Serup P 2005 Genetic determinants of pancreatic epsilon-cell development. Developmental Biology 286 217-224.

Houweling AC, Dildrop R, Peters T, Mummenhoff J, Moorman AF, Ruther U \& Christoffels VM 2001 Gene and cluster-specific expression of the Iroquois family members during mouse development. Mechanisms of Development 107 169-174.

Huotari MA, Miettinen PJ, Palgi J, Koivisto T, Ustinov J, Harari D, Yarden Y \& Otonkoski T 2002 ErbB signaling regulates lineage determination of developing pancreatic islet cells in embryonic organ culture. Endocrinology 143 4437-4446.

Itoh Y, Kawamata Y, Harada M, Kobayashi M, Fujii R, Fukusumi S, Ogi K, Hosoya M, Tanaka Y, Uejima H et al. 2003 Free fatty acids regulate insulin secretion from pancreatic beta cells through GPR40. Nature 422 173-176.

Jaszai J \& Brand M 2002 Cloning and expression of Ventrhoid, a novel vertebrate homologue of the Drosophila EGF pathway gene rhomboid. Mechanisms of Development 113 73-77.

Jensen J, Serup P, Karlsen C, Nielsen TF \& Madsen OD 1996 mRNA profiling of rat islet tumors reveals nkx 6.1 as beta-cell-specific homeodomain transcription factor. Journal of Biological Chemistry 271 18749-18758.

Jensen J, Heller RS, Funder-Nielsen T, Pedersen EE, Lindsell C, Weinmaster G, Madsen OD \& Serup P $2000 a$ Independent development of pancreatic alpha- and beta-cells from Neurogenin3expressing precursors - a role for the notch pathway in repression of premature differentiation. Diabetes 49 163-176.

Jensen J, Pedersen EE, Galante P, Hald J, Heller RS, Ishibashi M, Kageyama R, Guillemot F, Serup P \& Madsen OD $2000 \mathrm{~b}$ Control of endodermal endocrine development by Hes-1. Nature Genetics 24 $36-44$.

Kaneto H, Kajimoto Y, Fujitani Y, Matsuoka T, Sakamoto K, Matsuhisa M, Yamasaki Y \& Hori M 1999 Oxidative stress induces p21 expression in pancreatic islet cells: possible implication in beta-cell dysfunction. Diabetologia 42 1093-1097.

Karlsson E 2001 The role of pancreatic chromogranins in islet physiology. Current Molecular Medicine 1 727-732.

Kim SK \& Hebrok M 2001 Intercellular signals regulating pancreas development and function. Genes and Development 15 111-127. 
Kwon NS, Nathan CF \& Stuehr DJ 1989 Reduced biopterin as a cofactor in the generation of nitrogen oxides by murine macrophages. Journal of Biological Chemistry 264 20496-20501.

Laffranchi R, Schoedon G, Blau N \& Spinas GA 1997 Tetrahydrobiopterin synthesis precedes nitric oxide-dependent inhibition of insulin secretion in INS-1 rat pancreatic beta-cells. Biochemical and Biophysical Research Communications 233 66-70.

Lebel M, Agarwal P, Cheng CW, Kabir MG, Chan TY, Thanabalasingham V, Zhang X, Cohen DR, Husain M, Cheng SH et al. 2003 The Iroquois homeobox gene Irx2 is not essential for normal development of the heart and midbrain-hindbrain boundary in mice. Molecular and Cellular Biology 23 8216-8225.

Matsumoto K, Nishihara S, Kamimura M, Shiraishi T, Otoguro T, Uehara M, Maeda Y, Ogura K, Lumsden A \& Ogura T 2004 The prepattern transcription factor Irx2, a target of the FGF8/MAP kinase cascade, is involved in cerebellum formation. Nature Neuroscience 7 605-612.

Mears D 2004 Regulation of insulin secretion in islets of Langerhans by $\mathrm{Ca}(2+)$ channels. Journal of Membrane Biology 200 57-66.

Miettinen PJ, Huotari M, Koivisto T, Ustinov J, Palgi J, Rasilainen S, Lehtonen E, Keski-Oja J \& Otonkoski T 2000 Impaired migration and delayed differentiation of pancreatic islet cells in mice lacking EGF-receptors. Development 127 2617-2627.

Murtaugh LC \& Melton DA 2003 Genes, signals, and lineages in pancreas development. Annual Review of Cell and Developmental Biology 19 71-89.

Ohlsson H, Karlsson K \& Edlund T 1993 Ipf1, a homeodomaincontaining transactivator of the insulin gene. EMBO Journal 12 $4251-4259$.

Pedersen AH \& Heller RS 2005 A possible role for the canonical Wnt pathway in endocrine cell development in chicks. Biochemical and Biophysical Research Communications 333 961-968.

Petri A, Fleckner J \& Matthiessen MW 2004 Array-A-Lizer: a serial DNA microarray quality analyzer. BMC Bioinformatics 512.

Prado CL, Pugh-Bernard AE, Elghazi L, Sosa-Pineda B \& Sussel L 2004 Ghrelin cells replace insulin-producing beta cells in two mouse models of pancreas development. PNAS 101 2924-2929.

R Development Core Team. R: a language and environment for statistical computing, 2005. http://www.r-project.org.

Rutledge BJ, Zhang K, Bier E, Jan YN \& Perrimon N 1992 The Drosophila spitz gene encodes a putative EGF-like growth factor involved in dorsal-ventral axis formation and neurogenesis. Genes and Development 6 1503-1517.

Sakai Y, Hosaka M, Yoshinaga A, Hira Y, Harumi T \& Watanabe T 2004 Immunocytochemical localization of secretogranin III in the endocrine pancreas of male rats. Archives of Histology and Cytology $\mathbf{6 7}$ $57-64$.

Sander M, Neubuser A, Kalamaras J, Ee HC, Martin GR \& German MS 1997 Genetic analysis reveals that PAX6 is required for normal transcription of pancreatic hormone genes and islet development. Genes and Development 11 1662-1673.

Schwitzgebel VM, Scheel DW, Conners JR, Kalamaras J, Lee JE, Anderson DJ, Sussel L, Johnson JD \& German MS 2000 Expression of neurogenin3 reveals an islet cell precursor population in the pancreas. Development 127 3533-3542.

Slack JMW 1995 Developmental biology of the pancreas. Development 121 1569-1580.

Smyth GK, Michaud J \& Scott HS 2005 Use of within-array replicate spots for assessing differential expression in microarray experiments. Bioinformatics 21 2067-2075.

Soares ML, Centola M, Chae J, Saraiva MJ \& Kastner DL 2003 Human transthyretin intronic open reading frames are not independently expressed in vivo or part of functional transcripts. Biochimica et Biophysica Acta 1626 65-74.

St Onge L, Sosa-Pineda B, Chowdhury K, Mansouri A \& Gruss P 1997 Pax6 is required for differentiation of glucagon-producing alphacells in mouse pancreas. Nature 387 406-409.

Tayeh MA \& Marletta MA 1989 Macrophage oxidation of L-arginine to nitric oxide, nitrite, and nitrate. Tetrahydrobiopterin is required as a cofactor. Journal of Biological Chemistry 264 19654-19658.

Thor S, Ericson J, Brannstrom T \& Edlund T 1991 The homeodomain LIM protein Isl-1 is expressed in subsets of neurons and endocrine cells in the adult rat. Neuron 7 881-889.

Urban S, Lee JR \& Freeman M 2002 A family of Rhomboid intramembrane proteases activates all Drosophila membrane-tethered EGF ligands. EMBO Journal 21 4277-4286.

Wierup N, Svensson H, Mulder H \& Sundler F 2002 The ghrelin cell: a novel developmentally regulated islet cell in the human pancreas. Regulatory Peptides 107 63-69.

Wilson ME 2003 Gene expression cascades in pancreatic development. Mechanisms of Development 120 65-80.

Yoshihara M \& Montana ES 2004 The synaptotagmins: calcium sensors for vesicular trafficking. Neuroscientist 10 566-574.

Zhang J, Carey V \& Gentleman R 2003 An extensible application for assembling annotation for genomic data. Bioinformatics (Oxford, England) 19 155-156.

Received 23 May 2006

Accepted 9 June 2006 